$1(28) / 2015$

\author{
Jolanta Kruk \\ Elbląska Uczelnia Humanistyczno-Ekonomiczna \\ jolanta.i.kruk@gmail.com
}

\title{
Metodyka jako praktyka kulturowa (archetypowa). Ku źródłom zmiany w dydaktyce
}

\section{Summary \\ Teaching methodology as a cultural (archetypal) practice. Towards the sources of change in didactics}

This article is an introduction to the discussion on the essence of teaching methodology and the changes in its forms in contemporary culture. Two approaches to methodology are proposed: as a socially collective praxis, often unconsciously drawing on cultural practices, and as a so-called expert methodology - a collection of patterns of proper execution, which are a manifestation of the power/knowledge relation in the field of education. Psychology and cognitive science reports confirm that expert methodology is now losing its theoretical justification. The adoption of the concept of cultural (archetypal) methodology gives a chance of a deeper change in the practice of education, whose avant-garde are the concepts of the "reversed class" and of learning as a "dispersed" study, which consists of: equipment, material environment, and network interactions.

Słowa kluczowe: dydaktyka, metodyka nauczania, praktyka kulturowa, praktyka kształcenia, środowisko kształcenia

Keywords: didactics, teaching methodology, cultural practice, teaching practice, learning environment

\section{Wprowadzenie}

Zastanawiając się nad możliwościami dokonywania postulowanej przez środowiska pedagogiczne zmiany w dzisiejszych praktykach szkolnych, warto zatrzymać się przy kontekście metodycznym, który im towarzyszy. Metodyka szkolna stanowi nieodłączny element czynności nauczyciela w sferze dydaktycznej, rzuca na nie obszerny cień, a pomimo to rzadko jest dostrzegana i wskazywana wprost jako istotny czynnik uruchamiający bądź blokujący oczekiwane korekty w teorii kształcenia i praktyce szkolnej. Wydaje się, że nie jest to przypadkowe, a poszukiwanie odpowiedzi o możliwości realizowania pożądanej zmiany należałoby rozpocząć od bliższego przyjrzenia się fenomenowi, jakim jest metodyka zarówno jako konstrukt teoretyczny, jak i kategoria ściśle czynnościowa.

Metodyka funkcjonuje w świadomości pedagogów zarówno w sferze deklaratywno-profesjonalnej, jak również w podświadomym repertuarze podejmowanych codziennie 
czynności dydaktycznych. Interesującą i specyficzną cechą metodyki jest jej pewien swoisty dogmatyzm, uniemożliwiający kwestionowanie przyjętych procedur postępowania, nawet jeśli ich uzasadnienie od dawna jest nieaktualne ze względu na zmianę paradygmatu, w której osadzona była dana koncepcja metodyczna. Trudno też oprzeć się poczuciu, iż w świecie rozproszonych źródeł wiedzy, ustawicznie multiplikowanych informacji oraz stale udoskonalanych narzędzi hipertekstualnego przekazu, metodyka jawi się jako bezpieczna przystań pedagogicznej niezmienności. To nic, że nasza wiedza o pamięci i jej mechanizmach wskazuje, jak niepotrzebne i szkodliwe jest wymaganie zapamiętywania przez ucznia pakietów testowej niby-wiedzy, to nic, że zasada poglądowości dawno straciła swe psychologiczne uzasadnienie oparte na idei odzwierciedlenia, to nic, że tzw. cele operacyjne w odniesieniu do twórczych poszukiwań uczących się skutecznie blokują takie działania, to nic wreszcie, że choć praca w zespole i nieskrępowana komunikacja są takich poszukiwań warunkiem, to i tak oczekuje się efektu uprzednio określonego w podstawie programowej, bo poszukujący uczeń, a - co gorsza - poszukujący nauczyciel tak jednoznacznego efektu raczej nie gwarantują.

W tym kontekście możemy zadać sobie pytanie - czym jest metodyka, której władza sięga daleko poza szkolne mury, pozostawiając żywe wspomnienia przewidywalnego toku lekcji oraz pytań, na które uczeń stara się znaleźć tę właściwą odpowiedź, nawet jeśli nie on owo pytanie sformułował. Od wielu lat w dydaktyce (również rodzimej), rozluźnieniu uległ gorset metodyczny, na który składa się opis synchronicznych czynności ucznia i nauczyciela oraz towarzyszących im reguł poprawnego wykonania. Jeśli jednak zajrzymy do podręczników współczesnego kształcenia, przekonamy się, że pewne cechy konstytutywne dla pojęcia „metodyka” zostały zachowane - w zmienionej wprawdzie - ale nadal charakterystycznej postaci. Sądzę, że warto prześledzić, co składa się na ów niewidoczny gorset metodyczny, by następnie zastanowić się, jaka jest szansa na jego rozluźnienie czy wręcz odrzucenie w procesie krytycznej reinterpretacji.

\section{Metodyka jako zestaw technik i praktyka kulturowa}

Pytając o to, czym jest metodyka nauczania ${ }^{1}$, możemy przyjąć różne perspektywy opisu tego fenomenu. Chciałabym wyróżnić dwie możliwe płaszczyzny jego rozumienia:

1. Metodyka jako praktyka społeczna utrwalająca dyskurs władzy/wiedzy, operująca wzorami zachowań w obrębie instytucji edukacyjnych; wzory te wskazują reguły poprawnego wykonania i są nauczycielowi dostarczane z zewnątrz ${ }^{2}$.

\footnotetext{
1 W podręcznikach dydaktyki określenie „metodyka” pojawia się zazwyczaj w dwóch ujęciach, jako: a) „dydaktyka przedmiotowa”, czyli „zbiór szczegółowych dyrektyw, określający sposoby prawidłowego wykonywania czynności dydaktycznych” (Bereźnicki 2007: 16); b) „teorie uczenia się poszczególnych przedmiotów" (Kupisiewicz 2000: 18). To drugie podejście silniej związuje metodykę z dydaktyką rozumianą jako nauka o procesach uczenia się i nauczania.

2 Takich wzorów może dostarczać na przykład metodyka motessoriańska czy też metodyka wyprowadzona z idei szkoły transmisyjnej. W mniejszym stopniu „metodyzacji” poddaje się szkoła C. Freineta, z założenia nastawiona na poszukiwanie samodzielnych rozwiązań praktycznych.
} 
2. Metodyka postrzegana szerzej, jako praktyka czerpiąca wzory zachowań z zasobów kultury i przez to podlegająca zmianom; wzory są wytwarzane zawsze wewnątrz danej grupy, dla której pełnią one konieczną funkcję regulatywną (np. sposób wykorzystania danej gry dydaktycznej itp.).

W pierwszym ujęciu metodyka, zwana też dydaktyką szczegółową wyjaśnia jak formułować cele, treści, metody i formy organizacyjne w odniesieniu do konkretnego przedmiotu (Kupisiewicz 2012: 29). Cechami tak rozumianej metodyki jest standaryzacja, normalizacja w postaci zasad dydaktycznych oraz operacjonalizacja przyjętych celów kształcenia. W opracowaniach metodycznych napotykamy zróżnicowane pod względem szczegółowości zestawy wskazówek dla nauczycieli, gotowe scenariusze, konspekty, pakiety i inne pomoce ułatwiające tok kształcenia (por.: Okoń 2003, Kupisiewicz 2012, Bereźnicki 2007).

Metodyka zatem lokuje się w sferze znormalizowanych praktyk, zawierających opis procedur, których poprawne wykonanie gwarantuje osiągnięcie wcześniej sformułowanego celu dydaktycznego. W podręcznikach z zakresu dydaktyk przedmiotowych wiedza została zoperacjonalizowana tak, by można było ją wdrożyć w szkole bez szczególnych zmian. W efekcie zarysowana wizja realizacji praktyk metodycznych odcina je od kontekstu prowadząc do zubożenia sensu wykonywanych codziennie czynności i powodując ich rytualizację.

Drugie ujęcie metodyki, rozumianej jako praktyka kulturowa, odnoszę do wielu obszarów aktywności społecznej, gdzie czynności metodyczne stanowią uświadomioną kontynuację wcześniej nabytych wzorów. Sztuka pisania, czytania i rozumienia tekstu była uprawiana już w starożytnych szkołach z zachowaniem ściśle określonych kroków metodycznych ${ }^{3}$. Tysiące lat temu w Egipcie adepci uczyli się poprawnego trzymania pędzelka i używania czarnego i czerwonego tuszu, a dopiero w trzecim stuleciu p.n.e zamiast pędzelka wprowadzono w Grecji pióro. Cały proces pisania i czytania podzielony na kroki wtopiony był w kontekst kultury, w której powstawał zapisywany i odczytywany tekst. Ponieważ pierwotne pismo egipskie, oparte na ideogramach, mogło być odczytywane niejednoznacznie, pojawiły się znaki (determinatywy) umożliwiające zrozumienie intencji tekstu. Świadomość wieloznaczności pisma, towarzysząca dawnym twórcom metodyki hieroglificznej, doprowadziła do stworzenia przestrzeni dla interpretacji dawnych sposobów zapisywania myśli ludzkiej.

Śledząc ewolucję pisma wraz z zadziwiającym powrotem ideogramów we współczesnej komunikacji cyfrowej możemy przyjąć, iż metodyka rozumiana jako praktyka kulturowa stanowi otwarty zasób sposobów użytkowania dynamicznie zmieniających się narzędzi komunikacji społecznej, pozostających w stałej interakcji z ich użytkownikami. Zauważamy jednocześnie, że techniki towarzyszące interakcjom cechuje płynność wynikająca z kulturowego przyspieszenia, będącego pochodną cyfrowego interfejsu wymuszającego zmianę wzorów komunikacji.

W nawiązaniu do idei „nauczania wyprzedzającego” (por. Dylak 2013) możemy współcześnie mówić o różnych praktykach „metodyk wyprzedzających”, czyli takich,

3 http://www.wsp.krakow.pl/whk/sokol.html, 6.04.2014. 
które podążają za zmianą w praktykach społecznych, starając je rejestrować, interpretować i wykorzystywać jako niezbędne narzędzia wyjaśniania, udostępniania, tworzenia warunków pozyskiwania bądź przekształcenia wiedzy i informacji. Przykładem współczesnych wyprzedzających praktyk może być Koalicja na rzecz otwartej edukacji, której celem jest uwolnienie i upowszechnienie treści o charakterze edukacyjnym i wprowadzenie ich do domeny publicznej, tak by zainteresowani mogli swobodnie z nich korzystać4. Inne domeny obecne $\mathrm{w}$ sieci, takie jak nauczyciel.pl, platformy edukacyjne korzystające z mobilnych urządzeń na zasadzie „własna szkoła w kieszeni”, tworzą sferę wzorów kształcenia równolegle i niezależnie od spetryfikowanych wzorów metodycznych. Takim przykładem o cechach standaryzacji jest niedawno zmodernizowany sposób korzystania archiwów państwowych. Ze względu na cyfryzację systemu ich porządkowania zadanie to ma obecnie spełniać Centralna Komisja Metodyczna ${ }^{5}$. Planowana cyfryzacja zbiorów i ich standaryzacja oznacza zmianę w metodyce opracowywania tekstów archiwalnych, a co za tym idzie - zmianę w sposobach ich interpretowania. Nie wiadomo jednak, czy towarzysząca temu standaryzacja nie spowoduje - tak jak to ma miejsce w szkolnictwie w przypadku egzaminów zewnętrznych - ograniczenia przestrzeni tworzenia swobodnych koncepcji i form prac nad archiwaliami.

Przykładów praktyk metodycznych, wtopionych w kontekst kultury i wyrastających z niej, znajdujemy we współczesnej edukacji tak wiele, jak liczne są niezależne próby nauczycielskich innowacji i poszukiwań dydaktycznych. Zarówno w opracowaniach pedagogicznych, jak też w praktyce szkolnej opisywane i realizowane są liczne rozwiązania o charakterze eksperymentalnym, partycypacyjnym i systemowym ${ }^{6}$. Największe ich nasilenie można było zaobserwować w okresie przełomu lat 90. ubiegłego wieku. Niestety, obecnie niezależność poszukiwań nauczycieli została mocno ograniczona przez scentralizowaną administrację i oświatową biurokrację. Jednak nie wydaje się, by była to jedyna przyczyna zaniku spontanicznych poszukiwań metodycznych i dydaktycznych w sferze szkolnej (a nie edukacji) ${ }^{7}$. Dlatego chciałabym bliżej przyjrzeć się problematyce

\footnotetext{
${ }^{4}$ Skład KOE poszerza się, obecnie obejmuje m.in. Stowarzyszenie Bibliotekarzy Polskich, Fundację Kolonia Artystów, Fundację Soc-Lab, Fundację Wolnego i Otwartego Oprogramowania.

5 Na stronie Naczelnej Dyrekcji Archiwów Państwowych czytamy: Naczelny Dyrektor Archiwów Państwowych w dniach 10 i 11 grudnia 2013 r. podpisat decyzje, przygotowane przez Departament Archiwistyki NDAP, powotujace nowy sktad Centralnej Komisji Metodycznej oraz zespoly naukowe, których celem jest wprowadzenie standardu opisu materiałów archiwalnych, wskazówek metodycznych dotyczacych zasad opracowania materiałów archiwalnych oraz wskazówek metodycznych dotyczacych sporzadzania indeksów uwzględniających potrzebę tworzenia zintegrowanego systemu informacji archiwów. Źródło: http://www.archiwa.gov.pl/pl/component/content/article/63-aktualnosci/3885-metodyka-archiwalna-z-pe rspektywy-systemow-informatycznych.html, 7.04.2014.

${ }_{6}$ Nie sposób wymienić wszystkich pozycji poruszających problem działania zaangażowanego w sferze sztuki. Z różnych pozycji teoretycznych na ten temat piszą w pracy zbiorowej: A. Potocka (2002), R.W. Kluszyński (2010), D. Koczanowicz (2008).

7 Rozziew pomiędzy praktyką instytucji (metodyką szkolną) a praktykami edukacyjnymi bardzo dobrze ilustrują przykłady wykorzystywania mediów w szkole i poza nią.
} 
osadzenia metodyki nauczania w praktykach kulturowych w sferze społecznej oraz ich teoretycznemu ugruntowaniu.

\section{Metodyka jako zapis praktyk normalizujących osadzonych w kulturze}

Klasyczne podejście do kultury traktuje ją jako strukturę jednorodną, ożywianą mitami wspomagającymi poczucie wspólnoty międzyludzkiej, której symboliczne praktyki i procesy inkulturacji pełnią rolę wspomagającą utrzymanie społecznego ładu. Zarówno metodyka jak i kultura w tym paradygmacie mają charakter oświeceniowy, w którym nie ma miejsca na nieciągłość, ambiwalencję i sprzeczności. Socjologowie i antropolodzy są zgodni, iż kultura nie może obecnie być ujmowana jako byt jednorodny i całościowy. Nawet w ujęciu teorii społeczno-regulacyjnej zjawiska kulturowe opisywane są w kategoriach cząstkowości, fraktalności i nieusuwalnej różnicy (Burszta 2001:167). Znacząca w tym kontekście płaszczyzna opisu kultury jako solidnego gmachu, w którym następuje scalenie teorii i praktyk w społeczeństwach, musi zostać przesunięta w kierunku bardziej niepewnych terytoriów, jakimi są cząstkowe i jednostkowe rejestracje nie zawsze zrozumiałych działan symbolicznych i ekspresji w różnych kodach kulturowych. Na tym niejednoznacznym obszarze kultura postrzegana jest jako zestaw praktyk społecznych zasilanych ideami czerpanymi z walczących o dominację podmiotów społecznych oraz dyskursami i teoriami będącymi źródłem (nie)świadomych wzorów zachowań kulturowych. Metodyki można więc traktować jako formy takich praktyk. W warunkach instytucjonalnych nasycane są one kontekstem pełniącym funkcję normalizującą w społecznym dyskursie władzy/wiedzy. Dyskurs ten wytwarza specyficzny kod typu eksperckiego, do którego na gruncie metodyki należą takie wzorce wykonawcze, jak: poprawna realizacja konspektu, scenariusza, celów operacyjnych czy sylabusów...

Metodyka jako praktyka społeczna sytuuje się w polu władzy/wiedzy, dominując nad doświadczeniem edukacyjnym ${ }^{8}$ i odbierając pierwotnie obecny w nim sens. Wdrukowując zapisany w krokach metodycznych ład, osoby korzystające ze wskazówek dydaktycznych osiągają efekt socjalizacyjny, co jest gwarantem niekolizyjnego przekazu treści szkolnych. W ten sposób metodyka pełni funkcję narzędzia normalizującego wszystkich uczestników procesu dydaktycznego (uczniów, nauczycieli, biurokrację szkolną i samorządową) w akcie symbolicznego przetwarzania treści szkolnych w „metodyczny produkt”. W miejsce uwspólnionego sensu pojawia się oparte na zabiegach rytualizujących uzasadnienie władzy administracji oświatowej, co hamuje naturalną dynamikę procesów poznawczych i utrudnia kooperację uczących się. Przestrzeń doświadczenia edukacyjnego pomniejsza się, ustępując miejsca znormalizowanym fazom dydaktycznego rytuału.

\footnotetext{
8 Doświadczenie edukacyjne ujmuję zgodnie z opisem dokonanym przez A. Jurgiel-Aleksander jako naturalnie wpisane w sposób bycia czlowieka w świecie (2013: 30-31). Jest ono przeciwstawione traktowniu edukacji jako instrumentu adaptacyjnego względem rynku kompetencji i standaryzującego drogę uczenia się jednostki wedtug administracyjnych procedur (tamże).
} 


\section{Niepewne osadzenie teoretyczne metodyki normalizującej}

Należałoby jednak zapytać o rzeczywiste ugruntowanie upowszechnianych w procesie nauczania niektórych wzorców metodycznych, gdyż - jak wskazują liczne opracowania i materiały z tego zakresu - zakłada się, że istnieje jakieś głębsze teoretycznie i społecznie trwałe uzasadnienie wielu praktyk obecnych w dzisiejszej szkole, realizowanych w oparciu o precyzyjne wskazówki. Odwołując się do wybranych przykładów, chciałabym poddać w wątpliwość owe bezdyskusyjne uzasadnienia. Ich moc perswazyjna jest bardzo silna i oparta na przekonaniu o nieomylnej skuteczności działań podejmowanych w sferze poznawczo-socjalizacyjnej. Korzystanie z niegruntowanych teoretycznie uzasadnień może być nie tylko nieskuteczne dydaktycznie, ale wręcz działać w sposób utrwalający transmisyjny model przekazu dydaktycznego. Jak pisze Małgorzata Żytko, (...) trudno się dziwić, że wśród nauczycieli jest wielu zwolenników modelu instrukcyjnego (edukacji), bo wlaściwie tego się od nich oczekuje. Nie wiem tylko, na ile sa oni świadomi podstaw teoretycznych swojego dziatania $i$ w jakim stopniu ich sposób pracy jest efektem (...) ulegania wzorom (podkr. JK) rozpowszechnionym w różnych materiałach metodycznych (2010: 42).

$\mathrm{W}$ takim kontekście ogromnego znaczenia nabiera świadome korzystanie z owych wzorów, krytyczne ich studiowanie i równoległe nabywanie umiejętności tworzenia własnych rozwiązań metodycznych. Krytyczne przeszukiwanie źródeł leżących u podłoża zasad dydaktycznych i towarzyszących im wskazówek oraz wiedza o mechanizmach percepcji i procesach poznawczych są koniecznymi warukiami sensownego poruszania się w gąszczu różnorodnych koncepcji współczesnego uprawiania szkolnej i pozaszkolnej dydaktyki. Chciałabym zwrócić uwagę na kilka znaczących spostrzeżeń w tym zakresie.

\section{A. Wiedza o funkcjonowaniu umyslu}

Badacze umysłu człowieka są zgodni, że nauki kognitywne i towarzysząca im wiedza o funkcjonowaniu mózgu, pomimo ogromnego jej rozszerzenia w ostatnich latach, nadal nie daje pełnych odpowiedzi na pytania o mechanizmy powstawania i funkcjonowania świadomości. Wiadomo, że dotychczasowe modele oparte na koncepcji mechanistycznej, nie są zadowalające, gdyż jak pisze A. Revonsuo, (...) tak naprawdę nie znamy dotąd fundamentalnych zasad funkcjonalnej organizacji mózgu (2009: 283). Szczególne trudności dotyczą prób połączonej eksploracji poziomu neuronalnego i kognitywnego struktur mózgu/umysłu. Badanie świadomości na poziomie procesów percepcji, poznania i nadawania sensu napływającym i przetwarzanym informacjom wymaga bowiem zintegrowania z badaniami nad poziomem aktywności neuronalnej mózgu. Jak dotąd wiedza na ten temat jest wciąż cząstkowa (tamże: 287). Wyrafinowane metody obrazowania aktywności wybranych obszarów mózgu dają materiał trudny do interpretacji. Badacze nie uzyskują bowiem pewności, czy rejestrowane sygnały świadczą o faktycznie istotnych, czy też raczej o przypadkowych zdarzeniach mentalnych (tamże: 294). W tym kontekście pojawiają się opinie, że badanie świadomości leży poza zasięgiem nauk empirycznych, co 
jest może wnioskiem nazbyt pesymistycznym. Tym niemniej krytycznie należy traktować próby natychmiastowego i niepogłębionego refleksją wykorzystywania doniesień badawczych z tego zakresu, tak jak ma to ostatnio miejsce w obrębie tzw. neurodydaktyki ${ }^{9}$ (por. Żylińska 2013).

Jeśli zgodzimy się ze stwierdzeniem, iż umysł to coś więcej niż mózg, musimy zgodzić się także, że nie mamy pełnego wglądu w ten fenomen, pomimo coraz większej liczby doniesień eksperymentalnych popartych nowoczesnymi technikami badawczymi. Nie wiemy też naprawdę, czy sygnaty EEG i MEG odzwierciedlają aktywność jakiegoś funkcjonalnie istotnego poziomu organizacji czy tylko (...) szum elektrycznego hałasu (Revonsuo 2009: 295). Luka pomiędzy wiedzą o świadomości a neuronalnymi opisami funkcjonowania i organizacji struktur mózgu nie daje możliwości sformułowania zestawu pewnych i jednoznacznych wskazań zwiększających efektywność rozwiązań dydaktycznych i metodycznych, ponieważ opisy konstruowania świadomego umysłu w dużej mierze opierają się na modelach i metaforach. Istniejące rozbieżności pomiędzy naukami psychologicznymi, kognitywistyką, neurobiologią a wiedzą dydaktyczną i formułowanymi przez nią wzorami praktyk (metodyką) pozostawiają szeroki obszar do działań intuicyjnych i dalszych poszukiwań pedagogicznych. Miejscem pracy nauczyciela nie jest bowiem - jak twierdzą przedstawiciele neurodydaktyki - mózg ucznia ani nawet jego umysł, lecz zmienna i zróżnicowana sytuacja, w której jest on znurzony wraz z uczniami we wzajemnej dynamicznej interakcji. Na jej kontekst składają się warunki społeczno-kulturowe, które dopiero w połączeniu z wiedzą psychologiczną, kognitywną czy szerzej - humanistyczną - mogą ułatwiać formułowanie wzorów metodycznych.

Przywołane argumety nie oznaczają jednak, że neuronauki nie mogą stanowić znaczącego wsparcia dla poszukiwań dydaktycznych i metodycznych. Sądzę, że aktualizacja tej wiedzy jest wręcz warunkiem renegocjacji szkolnych i pozaszkolnych wzorów metodycznych.

\section{B. Badania nad świadomością}

W badaniach nad świadomością formułowane są hipotezy odnoszące się do natury zjawisk mentalnych, zgodnie z którymi zbadanie funkcjonowania neuronalnych struktur mózgu wyjaśni podłoże procesów percepcyjnych oraz świadomości, szczególnie w odniesieniu do wzroku (por. Klawiter 2012: 372 i nast.). Badacze ostatecznie odrzucili kartezjańską ideę „oka umysłu” czyli swoistego centrum dyspozycyjnego, na rzecz tzw. „koalicji neuronów" które zawiązują się w reakcji na sytuację zewnętrzną. Oznacza to, że stany mentalne mają znacznie bardziej rozproszone podłoże neurofizjologiczne, niż sądzono wcześniej, a także - co jest istotne z punktu widzenia praktyki pedagogicznej - nie ma jednoznacznie zdefiniowanego centrum decyzyjnego odnoszącego się do wielu funkcji umysłu a tym samym nie jest możliwe jednoznaczne sprecyzowanie wskazówek służą-

\footnotetext{
9 Samo określenie „neurodydaktyka” może budzić wątpliwości jako próba powrotu do neobehawioralnego modelu nauczania ugruntowywanego niekoniecznie w sposób właściwy wiedzą z zakresu neuronauk.
} 
cych efektywnemu wykonaniu określonych zadań dydaktycznych, jak np. precyzyjne polecenia w zadaniach testowych.

\section{Konstruowanie reprezentacji wiedzy a poglądowość}

Badania nad procesami percepcji prowadzą też do innych, zaskakujących stwierdzeń. Kognitywiści sformułowali szereg argumentów przeciwko „realizmowi naiwnemu”, który w teorii percepcji przybrał postać pojęcia tzw. świadomości odzwierciedlającej, co stało się podstawą do sformułowania jednej z najstarszych zasad dydaktycznych - zasady poglądowości. To, iż w akcie percepcji mamy do czynienia z faktycznym związkiem pomiędzy podmiotem poznającym a przedmiotem poznania, nie oznacza - jak pisze $Ł$. Przybylski (2012:138,141 i nast.) - iż powstała reprezentacja danego zjawiska jest wierną kopią percypowanego zjawiska. Akt percepcji jest bowiem oparty na wieloetapowym przetwarzaniu informacji, formułowaniu hipotez i oczekiwań w odniesieniu do doświadczenia, w którym staramy się wszelkimi sposobami wypełnić lukę poznawczą.

Oznacza to szereg istotnych wskazań dla praktyki dydaktycznej. Człowiek, aktywnie badając swe środowisko, wykorzystuje nie tylko dyspozycje zmysłowe i intelektualne, ale też kod enaktywny, czyli motorykę/działanie, stanowiące niezastąpione narzędzie gromadzenia informacji (tamże:144 i nast.). Inaczej ujmując - to świat zewnętrzny stanowi magazyn potencjalnych danych i jest rodzajem stale aktualizowanej pamięci zewnętrznej, z której czerpiemy w trakcie doświadczeń sensomotorycznych, niezastępowalnych w stosunku do magazynu wewnętrznego, jakim są zasoby wcześniej skonstruowanych reprezentacji i wiedzy pojęciowej. Dla praktyki metodycznej oznacza to, iż sensowna wydaje się idea delegowania źródeł wiedzy na zewnątrz. Obecnie tak realizowane są ,metodyki wyprzedzające", jak odwrócona klasa w interperatacji badawczej S. Dylaka (2013) czy też idea „rozproszonego nauczyciela” polegająca na uczeniu sieciowym zastępującycm skupione centrum dydaktyczne.

Liczne przykłady praktyk wspólnotowych wskazują, że zaangażowani w nie uczestnicy traktują proces uczenia się jako element szerszego zjawiska, jakim są interakcje z wbudowanymi mechanizmami percepcji społecznej. W opisach teoretycznych dawne kartezjańskie obiektywne „oko umysłu” zastąpione zostało przez rozproszone i krótkotrwałe koalicje poznawcze o wyraźnie zaznaczonym interesie poznawczym, odgrywającym decydującą rolę w przebiegu procsu percepcji i wpływającym na jej rezultat.

\section{Nabywanie wiedzy pojęciowej i uczenie się}

Powyższe spostrzeżenia mają swe konsekwencje w obszarze związanym z problematyką nabywania wiedzy pojęciowej i zaawansowanych procesów poznawczych. Od dawna w badaniach nad procesem tworzenia pojęć używa się koncepcji metafor z udziałem wiedzy naiwnej/uprzedniej. Wykazując tendencję do ujednolicania i nadawania cech koherencji wytwarzanym pojęciom i reprezentacjom badacze podkreślają, iż od czasów L. Wygotskiego nadal nie mamy pewności, jakie czynniki wpływają na sposób kategoryzacji podczas uczenia się nowych pojęć. W eksperymencie dotyczącym uczenia się pojęć 
podczas tworzenia sztucznych kategorii badani kierowali się wyraźnie wiedzą uprzednią (Piłat 2012:294). Dotyczy to również procesu rozumowania opartego na indukcji oraz wyjaśniania wybranych epizodów, ponieważ w każdym z badanych przypadków badacze odnotowali znaczący udział wiedzy uprzedniej. Doniesienia te korespondują z innymi ciekawymi obserwacjami dotyczącymi procesu uczenia się opartego na odzwierciedleniu. Mam tu na myśli często komentowane odkrycie znaczenia roli tzw. neuronów lustrzanych w trakcie mentalnego powielania czyichś zachowań. Jak się okazuje - uczenie się schematów ruchowych z udziałem neuronów lustrzanych dotyczy reprezentacji ruchowych już wcześniej częściowo uruchamianych. Inaczej to ujmując, uczenie się przez naśladownictwo jest efektywne wówczas, gdy uczący się ma przynajmniej częściowo opanowane określone wzory wykonania (Dziarnowska 2012:520). Być może więc eksponowane przez współczesną neurodydaktykę odkrycie znaczenia neuronów lustrzanych dla procesu uczenia się jest nieco przedwczesne, gdyż nie wyjaśnia sposobu konstruowania przez podmiot wiedzy oryginalnej, będącej efektem i warunkiem poznawczej zmiany rozwojowej. Tym niemniej badania neuronauk w dużym stopniu przyczyniają się do rozszerzenia interpetacji społecznego znaczenia wiedzy spontanicznej oraz rozumienia czyichś stanów mentalnych w procesie uczenia się. Określenie tej umiejętności jako „kompetencji społecznej” wprost odsyła dydaktyków do uzasadnień sformułowanych przez L. Wygotskiego mówiących o epizodach uczenia się, które w dojrzałej formie powtórnie pojawiają się w kontekście społecznym (Dziarnowska 2012: 525).

\section{Renegocjacje - metodyka archetypowa jako źródło praktyki dydaktycznej}

Wyodrębnione dwa ujęcia metodyki mogą być punktem wyjścia do dyskusji nad współczesnym wykorzystaniem bogatych zasobów wiedzy i wzorów metodycznych wypracowanych w przeszłości. Patrząc na metodykę i jej funkcje zauważamy, że możliwe są co najmniej dwa sposoby podejścia do jej praktycznego funkcjonowania w sferze edukacji i w kulturze:

1. Jako praktyki społecznej utrwalającej dyskurs władzy/wiedzy operującej wzorami zachowań w obrębie instytucji edukacyjnych. Wzory te wskazują reguły poprawnego wykonania i są nauczycielowi dostarczane z zewnątrz ${ }^{10}$, nie mając często pełnego zaplecza teoretycznego

2. Jako praktyki czerpiącej wzory zachowań z zasobów kultury i przez to podlegającej zmianom. Wzory są wytwarzane i negocjowane wewnątrz uczącej się grupy ${ }^{11}$.

\footnotetext{
${ }^{10}$ Jako przykład może posłużyć metodyka montessoriańska, która stanowi rozbudowany system pomocy i schematów metodycznych. Sądzę że praktykowanie tej metodyki powinno być stale renegocjowane $\mathrm{z}$ uwagi na nowe doniesienia z zakresu kognitywistyki, dlatego pytanie o to, w jakim stopniu materiał montessoriański daje okazję do konstruowania wiedzy, wydaje się uzasadnione.

${ }^{11}$ Niektóre systemy dobrze wypełniają ten opis, na przykład pedagogia C. Freineta czy szkoła Reggio Emillia.
} 
Drugie ujęcie może stać się obiecującym terenem renegocjacji funkcji metodyk w dzisiejszej szkole i kulturze. Chodzi o możliwość restauracji metodyki jako praktyki poprzez „odczytywanie" jej związków ze społeczeństwem, kulturą i teoriami interpretującymi jej dynamikę. Narzędziem tych odczytań może być wzór archetypowy, realizowany w początkowej fazie w formie zestawu technik o nieuświadomianych źródłach opartych na zachowaniach właściwych danej kulturze czasu i miejsca. Nie chodzi więc o odrzucenie wzorców, reguł czy zasad dydaktycznych, lecz o uświadomienie ich źródła, zdemaskowanie/ odrzucenie biurokratycznego przymusu a także ujawnienie gruntu teoretycznego i jego ewentualne zbadanie a nawet zakwestionowanie. Podejście to odwołuje się do fenomenu archetypu, którego struktura może pomóc w nabywaniu samodzielności dydaktycznej przez nauczyciela (Motycka 1992:186-187) ${ }^{12}$. Archetyp, przybierając formę praobrazu, ułatwia człowiekowi porządkowanie jego doświadczenia, jednakże pod warunkiem włączenia go do strumienia świadomego działania i zintegrowania go ze sferą świata społecznego i jego kulturowego budulca. Tym samym archetypy jako wzory praktyk społecznych dają jednostce poczucie ugruntowania wobec sprzeczności, z którymi się styka oraz zapobiegają oderwaniu świadomych struktur psychiki od nieuświadomionych korzeni, z których czerpie ona energię do działania.

Ugruntowanie archetypowe stanowi płaszczyznę dla odnajdywania się w kulturowych praktykach zbiorowości. Ponieważ wzorce wykonania mają charakter wspólnotowy, możliwa staje się np. weryfikacja założeń teoretycznych w formie etiud laboratoryjnych. Ich znaczenie nie polega na dokonywaniu szczególnych odkryć czy tworzeniu radykalnie nowych koncepcji metodycznych. Przeciwnie - poszczególne praktyki dydaktyczne mogą nas rozczarowywać swą oczywistością, niskiem poziomem oryginalności czy powielaniem znanych schematów metodycznych. Sądzę, że ich siła tkwi gdzie indziej - a jest nią zmiana postawy osoby uruchamiającej archetyp, dzieki któremu zyskuje szczególny rodzaj ugruntowania, które nie jest ani teoretyczne ani praktyczne, lecz stanowi formę „krytycznej filozofii technicznej”. Ujmując to w języku pedagogiki: nauczyciel - wchodząc $\mathrm{w}$ tryb laboratoryjny (a tym samym wychodząc $\mathrm{z}$ trybu naśladowania wzorca metodycznego) - ma przed sobą trzy etapy przejścia od archetypu do samodzielnego wykonania:

1. Intuicyjna (jak to mogę zrobić?).

2. Metrializacja i konkretyzacja idei (pomysł, np. scenariusze zajęć w postaci prototypów do dalszej weryfikacji).

3. Upowszechnienie (np. zestawy ćwiczeń, pomoce dydaktyczne) i włączenie w kontekst społeczny, uruchomienie interakcji (sieć).

Istotne jest połączenie wszystkich faz w postaci cyklu, w którym nie ma podziału na ekspertów i wykonawców a rozumienie sensu wykonywanych działań pogłebia się w miarę

\footnotetext{
${ }^{12}$ Całość archetypów to suma potencjalnych możliwości psychiki ludzkiej ograniczona do typowych doświadczeń fundamentalnych (Motycka 1992: 186). Proponując takie podejście do analizy fenomenu metodyki przypomnę, że archetyp to według C.G. Junga nieświadoma część osobowości, w której zostały wyryte, zapisane pewne instynkty, będące pierwotnymi składnikami przedracjonalnej psychiki.
} 
realizacji powziętego pomysłu. Jest tu miejsce na błędy, poprawki, powtórki i konfrontację z dotychczasową wiedzą.

Proponowane podejście do metodyki jest zbieżne ze współczesnymi poglądami filozofów nauki na współczesne procesy badawcze, gdzie odosobnione działania jednostek ustępują na rzecz badania „rozproszonego”, na który składają się - aparatura, środowisko materialne i interakcje w sieci (Afeltowicz 2011:73 i nast.). Wsparcie tego ujęcia strukturą archetypu może ułatwić znalezienie odpowiedzi na pytanie: „Jak to należy robić?”, ponieważ wiąże jednostkę z rozległym kontekstem jej działania, umożliwiając jej przejście od mglistej intuicji do sensownego wykonania. Odnosząc to do wzorców metodycznych, możemy przyjąć, że nauczyciel i uczeń są błądzącymi ekspertami w sztuce łączenia konceptu z jego wykonaniem.

\section{Literatura}

Afeltowicz Ł. (2011), Laboratoria $w$ działaniu. Innowacja technologiczna $w$ świecie antropologii nauki. Warszawa, Oficyna Naukowa.

Bereźnicki F. (2007), Dydaktyka kształcenia ogólnego. Kraków, Oficyna Wydawnicza „Impuls”.

Burszta W.J. (2001), Teoria kultury, czyli „dtużej klasztora niż przeora”. W: B. Kotowa, J Sójka, K. Zamiara (red.), Kultura jako przedmiot badań. „Studia Kulturoznawcze”, numer specjalny, Wydawnictwo Fundacja Humaniora.

Dylak S. (2013), Architektura wiedzy w szkole. Warszawa, Wydawnictwo Difin.

Dziarnowska W. (2012), Sposoby poznawania innych umysłów. W: M. Miłkowski, R. Poczobut (red.), Przewodnik po filozofii umystu, Kraków, Wydawnictwo WAM.

Jurgiel-Aleksander A. (2012), Doświadczenie edukacyjne w perspektywie andragogicznej. Studium biograficzno-fenomenograficzne. Gdańsk, Wydawnictwo Uniwersytetu Gdańskiego.

Kupisiewicz Cz. (2012), Dydaktyka. Podręcznik akademicki. Kraków, Oficyna Wydawnicza „Impuls".

Klawiter A. (2012), Świadomość. W: M. Miłkowski, R. Poczobut (red.), Przewodnik po filozofii umystu, Kraków, Wydawnictwo WAM.

Kluszyński R.W. (2010), Sztuka interaktywna. Od dzieła-instrumentu do interaktywnego spektaklu. Warszawa, Wydawnictwa Akademickie i Profesjonalne.

Koczanowicz D. (2008), Doświadczenie sztuki, sztuka życia. Wymiary estetyki pragmatycznej. Wroclaw, Wydawnictwo Naukowe Dolnośląskiej Szkoły Wyższej.

Motycka A. (1992), Po co filozofom nauki archetypy Junga? W: J. Niżnik (red.), Pogranicza epistemologii. Warszawa, Wydawnictwo IFiS PAN.

Okoń W. (2003), Wprowadzenie do dydaktyki ogólnej. Warszawa, Wydawnictwo Akademickie „Żak".

Piłat R. (2012), Uczenie się pojęć. W: M. Miłkowski, R. Poczobut (red.), Przewodnik po filozofii umystu, Kraków, Wydawnictwo WAM.

Potocka A. (2002), (red), Publiczna przestrzeń dla sztuki? Öffentlicher Raum für Kunst? Kraków-Wien, Bunkier Sztuki, inter esse.

Przybylski Ł. (2012), Procesy percepcyjne. W: M. Miłkowski, R. Poczobut (red.), Przewodnik po filozofii umystu, Kraków, Wydawnictwo WAM. 
Revonsuo A. (2009), O naturze wyjaśniania w neuronaukach. W: M. Urbański, P. Przybysz (red.), Funkcje umystu. „Poznańskie studia z filozofii humanistyki”, nr 8 (21), Poznań, Wydawnictwo Zysk i S-ka.

Żylińska M. (2013), Neurodydaktyka. Nauczanie i uczenie przyjazne mózgowi. Toruń, Wydawnictwo Naukowe Uniwersytetu Mikołaja Kopernika.

Żytko M. (2010), Pozwólmy dzieciom mówić i pisać. W kontekście badań umiejętności językowych trzecioklasistów. Warszawa, Wydawnictwo CKE. 